\title{
Foreign Direct Investment and Trade in the Asia-Pacific Region: Complementarity, Distance and Regional Economic Integration
}

\author{
Susan F. Stone \\ Productivity Commission of Australia \\ Bang Nam Jeon \\ Drexel University
}

\begin{abstract}
This paper investigates the relationship between FDI and trade in the AsiaPacific economies by examining the bilateral flows of trade and FDI in a crosssectional study. The estimation results based on the gravity model show a significant and positive relationship between trade and FDI, implying a complementary relationship. Estimated coefficients also imply that trade has a larger impact on FDI flows than such investment has on bilateral trade flows. It is evident that the distance between the home country and the host country is a significant resistance factor for trade, but not for FDI. The estimation results

* Correspondence address : Bang Nam Jeon, Department of Economics and International Business, Drexel University, 32nd and Market Streets, Philadelphia, PA 19104, Tel: (215) 895-2125, Fax: (215) 895-6975, e-mail address: JEONBANA@drexel. edu

** Authors are International Economist at Economics Research Branch, Productivity Commission, Melbourne, Australia, and Associate Professor of Economics and International Business at Drexel University, Philadelphia, U.S.A., respectively.

(C) 2000 - Center for International Economics, Sejong Institution. All rights reserved.
\end{abstract}


also suggest that the formation of APEC in 1989 has enhanced economic interdependence in trade, though not FDI yet, in the Asia-Pacific region.

- JEL classifications: F21, F15, O53

- Key Words: Complementarity Between FDI and Trade, APEC

\section{Introduction}

The rapid growth of foreign direct investment (FDI) and the recent discussions about international arrangements governing FDI, at the regional and multinational levels, have redirected attention to the relationship between FDI and trade. What are the common underlying determinants of FDI and trade? Does FDI substitute for, or complement, trade? If then, to what extent does this relationship take place? With the increasing importance of trade and investment flows in the world economy comes the continuing need to understand their relationship. FDI flows have grown at a compound annual rate of over 17 percent between 1987 and 1998. Seemingly unaffected by the Asian financial crisis, FDI inflows during 1998 increased by 39 percent over the year before reaching a new record level of $\$ 644$ billion, while FDI outflows reached $\$ 649$ billion. (UNCTAD 1999) Outward FDI stock in the world totaled $\$ 4.1$ trillion in 1998. The rapid increase in trade flows is equally impressive. World trade increased over 6 percent per annum between 1985 and 1999. Both the growth in trade and the growth in FDI have outstripped growth in world output. World GDP increased at an annual rate of just over 3 percent between 1985 and 1999.

Although the relationship between FDI and trade has been examined by many researchers with increasing frequency, it is imperative for businesses and policy makers alike to understand the inter-linkages between trade and FDI (UNCTAD 1996). Often trade and investment policies are set by different governing bodies. This often leads to contradictory strategies which may end up deterring both FDI and trade flows. It is important for policy makers to understand the inter-relationship between the two so that jointly strengthening policies can be developed.

One of the most important factors which have contributed to the impressive growth of FDI and trade is the increasing liberalization of trade and investment policies at the national and global levels. The trend towards the 
liberalization of regulatory regimes for FDI has continued during the postglobal financial crisis era. Under the auspices of the World Trade Organization (WTO), the global economy has furthered the liberalization of trade in traditional as well as non-traditional sectors. Policies concerning trade and FDI in agriculture and services have been liberalized further, and strategies for abolishing various forms of non-tariff barriers were addressed. Developing countries have been liberalizing their FDI regimes in the hope of obtaining access to developed countries' capital and technology. While, for the most part, the process of FDI liberalization has lagged behind that of trade liberalization, the annual growth rate of FDI flows has exceeded the growth rate of trade.

The purpose of this paper is to investigate the nature of the relationship between trade and FDI with an emphasis on the Asia-Pacific economies. The predominant nature of the trade and FDI relationship will be determined by examining bilateral flows of trade and FDI across the world economy in a cross sectional study using the gravity model. We will also examine the regional impact on these relationships, if any, by investigating the possible impact of a shared geographical location on the nature of trade and FDI flows. The impact of geographical location has been addressed so far in various forms in discussions of trade, but has not been applied empirically in an attempt to help explain the nature of FDI flows.

The Asia-Pacific region is a particularly important area of the world given its impressive growth, at least up until the recent 1997 Asian financial crisis. Foreign investment and trade have been critical parts of this growth in the region. The issue of the relationship between trade and FDI flows is important due to its policy implications in the region. Asian economies have been liberalizing their economies since the mid-1980s in an effort to sustain growth rates which have been the envy of the world until the recent 1997 financial crisis. However, we can pose important questions: if the increased FDI attracted through this liberalization policy cuts into exports, can growth and economic integration be expected to continue in the region? If the growth has truly been export-led, and if FDI flows and trade are shown to be predominately substitutes, what does that imply about the future of FDI liberalization and the growth prospects for Asia?

The paper will proceed as follows. Section II will discuss the theoretically 
projected relationship between trade and FDI flows. Section III will develop the gravity model and examine the data series. Section IV will present the results of the empirical test of the gravity equation on bilateral trade and FDI flows with emphasis on the Asia-Pacific region. Section V will reach the conclusions.

\section{The Inter-linkage between Trade and FDI}

The patterns of commodity trade and FDI share certain common underlying determinants, such as factor endowments, relative production costs, and macroeconomic environments, while there are also various influences that cause divergences between their patterns, such as specific locational factors including the host country policy. Trade and FDI are market responses to profit opportunities provided by differences between countries' production capabilities and consumption preferences. Different sectors tend to follow different patterns. For instance, FDI flows in the manufacturing industry tend to follow a product cycle trend. In the early stages of a product, producers look for the opportunity of exporting the product to overseas markets. As the product matures, FDI will lead to a reduction in exports as companies set up production facilities closer to their consumption base. As the product becomes further standardized, efficiency-based FDI will lead to increased exports as companies relocate production to decrease costs and export from this new production base. However, the nature of the manufacturing process has been changing in recent years, and companies are no longer necessarily following this linear pattern of production. FDI and trade often take place simultaneously. In addition, inter-sectoral FDI and trade are leading to new patterns for their interrelationship.

The complementarity or substitute relationship between trade and FDI may depend on the real motives of FDI conducted by multinational corporations (MNCs). For example, foreign investment undertaken to be closer to local markets may be considered a substitute for trade. An MNC may face a choice between exporting and FDI to serve a foreign market with a particular product, implying a competing relationship between trade (especially exports) and FDI (especially FDI outflows) from the MNC's perspective. Investment made to expand markets, on the other hand, does not necessari- 
ly displace existing trade but often gives rise to new trade flows. Vertical and horizontal integrations often lead to increased trade flows, consisting mostly of intra-firm trade, with components produced in one or more countries and assembled in the same or offshore countries. Here, FDI is tradeenhancing as it expands domestic consumption possibilities and imports, as well as increasing exports for the host economy. Investment for the purpose of extracting natural resources is usually undertaken to ensure that supply routes stay open, implying a complementary link.

A theory which has had some success in explaining broader patterns of FDI is the internalization theory. One of the important motivations of FDI is the desire on the part of the investing firm to increase efficiency by bringing all aspects of the operation in-house. This reduces transaction costs and increases control for the firm. The internalization theory implies a positive relationship between trade and FDI through vertical integration. As the firm internalizes much of its processes, the amount of trade between divisions would necessarily increase. This is because the investing firm would be importing components from one division and exporting its output to another. Thus, it is possible for the host country's imports and exports to rise as a result of FDI inflows under the internalization theory. However, if the majority of FDI is achieved through the acquisition of current suppliers and/or distributors, trade may not be affected.

The eclectic theory states that there is a mixture of motivating factors involved in FDI decisions and that only when all three are present, FDI will take place. The first factor is ownership. The investing firm must have some ownership advantage over its rivals such as technology, patent, trademark, management skills, or reputation. The second factor is the advantage of internalizing these ownership-specific abilities. The motivation for vertical integration is having in-house control over all stages of the process. Finally, according to the theory, there must be some locational advantage such as gains from comparative advantage of location specific factors. The three tenets of ownership, location, and internalization are each preconditions for FDI flows in the eclectic theory.

However, the eclectic theory provides no clear indication as to the relationship between trade and FDI flows. Ownership advantages, by themselves, imply less trade. If the firm invests due to ownership advantages, it is 
in place of exporting. Internalization, as already discussed, may lead to increased trade flows as different divisions import and export to other divisions along the verticalized process line. Location often implies a negative relationship. If FDI is chosen due to locational advantages, it would imply a decrease in trade. This is because exports are replaced by closer production in the host country market. Locational advantages relating to natural resources, however, imply an increase in trade as FDI extracts those resources for home country use. Yet, again, location seen in a regional context may lead to enhanced trade as the host country is used as a base through which the multinational corporations (MNCs) serve the entire region.

Naya and Ramstetter (1991) examined the trade propensities of domestic and foreign firms to investigate the relationship between FDI and trade in the Asia-Pacific region. They defined two propensity ratios: the export-sales ratio, which is the proportion of export sales to total sales, and the importcontent ratio, which is the proportion of imported inputs to total inputs employed in the production process. The export-sales ratio was high for multinational firms located in Korea, Taiwan, Singapore, and Thailand. This would seem to support the contention of a positive, or complementary relationship between FDI flows and trade in the region.

Further preliminary support for a complementary relationship can be found in Lucas (1993). Lucas developed a model of derived demand for foreign capital in seven Asian economies and found that FDI flows are more elastic with respect to aggregate demand in export markets than domestic demand. However, Lucas also found that FDI rises with greater costs within the home country but not with a corresponding increase in costs in rival host countries. This implies that cost differentials are not the sole driving force for FDI flows and that domestic market considerations play a role, indicating trade and FDI may indeed be substitutes.

Whether trade and FDI flows are complementary or supplementary is, therefore, an empirical question to be examined. The next section will develop an empirical model to investigate this issue, and describe the data used in the study. We will also investigate the different roles of distance between the home (exporting) country and the host (importing) country and regional economic integration as determinants of trade and FDI flows in the Asia- 
Pacific region.

\section{The Model and the Data}

\section{A. The Model}

We use the gravity model of bilateral trade, which has been developed and used in the recent literature of trade and geography, to investigate the relationship between trade and FDI flows and the distinctive roles of distance and regional integration in determining trade and FDI flows in the AsiaPacific region. The traditional gravity equation focuses on bilateral trade flows to predict or explain trade between nations. The model predicts that trade between countries depends positively on the size of their economies (measured by output and population, or per capita income) and inversely on the distance between them. The distinctive feature of the equation is its distance parameter which measures geographical or cultural proximity. The model, in the past, has been criticized for its lack of theoretical foundation. However, works by Anderson (1979), Thursby and Thursby (1987), Bergstrand (1989), and Deardorff (1997) have made great strides towards addressing this criticism. The model's empirical success, however, is widely known. ${ }^{1}$ The general form of the gravity equation is specified as follows:

$$
\log X_{i j}=\alpha_{0}+\alpha_{1} \log Y_{i}+\alpha_{2} \log Y_{j}+\alpha_{3} \log N_{i}+\alpha_{4} \log N_{j}+\alpha_{5} \log D_{i j}+\varepsilon_{i j}
$$

where: $X_{i j}$ : the value of trade between country $i$ and country $j$,

$Y_{i}, Y_{j}$ : income in the exporting and importing countries,

$N_{i}, N_{j}$ : the population in the exporting and importing countries,

$D_{i j}$ : the distance between country $i$ and country $j$, and

$\boldsymbol{\varepsilon}_{i j}$ : the log-normally distributed error term with $E\left(\boldsymbol{\varepsilon}_{i j}\right)=0$.

There are three reasons why the gravity model has recently regained its popularity in empirical studies of international trade: its empirical success at predicting bilateral trade flows, its improved theoretical foundations arising

1. Gravity models have been applied successfully to different types of flows, such as commuting, migration, and inter-regional and international trade. See Deardorff (1984) for a review of the application of the gravity equation to model bilateral trade flows.. 
mostly from modern theories of trade in imperfect substitutes, and a new interest in the subject of geography and trade. (Frankel 1997) The role of geography in determining trade patterns has received renewed interest of late. This economic geography theory states that historical geographic conditions often factor heavily in the development of certain industries in certain locations. These industries tend to become focused in one geographic region, due to many reasons. The development of a regional block of industries could be due to the proximity of a needed resource to the available pool of specialized (or non-specialized as the case may be) labor or end-market locations. In any event, this argument provides further justification for the consideration of a distance or geographic factor in explaining trade patterns, as well as the inclusion of the variables for regional blocs.

The recent trade literature has also employed the gravity model to detect the impact of various variables such as region, stage of development and, most importantly, geographical location on the patterns of trade flows. This equation is most useful in our study for several reasons. The equation easily accommodates the addition of the FDI variable, and the linear nature of the equation leads to easy interpretations of the resulting coefficients. We can also measure the regional impact through the use of regional dummy variables. Finally, the sign of the coefficient of the FDI variable will provide an indication of the nature of the trade/FDI relationship: i.e., if positive, a complementary relationship can be inferred, while a negative sign would indicate a substitution relationship.

The gravity-type equation for our purpose takes the following form:

$$
\begin{aligned}
& \log \text { Trade }(\mathrm{FDI})_{\mathrm{ij}}=\beta_{0}+\beta_{1} \log \mathrm{GDP} \mathrm{i}+\beta_{2} \log \mathrm{Pop}_{\mathrm{i}}+\beta_{3} \operatorname{logGDP} \mathrm{P}_{\mathrm{j}} \\
& +\beta_{4} \log \text { Pop }_{\mathrm{j}}+\beta_{5} \log \text { Distance }_{\mathrm{ij}}+\beta_{6} \log \mathrm{FDI}(\text { Trade })_{\mathrm{ij}} \\
& +\beta_{7} \mathrm{APEC}_{\mathrm{ij}}+\beta_{8} \mathrm{ASEAN}_{\mathrm{ij}}+\beta_{9} \mathrm{DEA}_{\mathrm{ij}}+\boldsymbol{\varepsilon}_{\mathrm{ij}}
\end{aligned}
$$

where trade $(F D I)_{i j}$ in equation (2) represents total bilateral trade/FDI flows between country $i$ and country $j$, where subscripts $i$ and $j$ identify the home (exporting) country and host (importing) country, respectively. GDP is gross domestic product, $P o p$ is the population, and Distance is the geographical distance between the two countries $i$ and $j^{2}$

As stated above, we are also looking for regional effects as they relate to 
the Asia-Pacific region. We believe that the region's dynamics provide stimulus to trade and foreign direct invest-ment over and above what can be explained by simple geographic proximity. Wei and Frankel (1994) have used an Asian dummy variable to examine the existence of an Asian trade bias. We have included APEC, ASEAN, and DAE dummy variables in the estimation equations. ${ }^{3}$ These represent dummies which take on a value of one when both country $i$ and country $j$ are members of the specific regional grouping and a value of zero otherwise. Thus, the equation states the trade(FDI) flows between two countries depend on each country's GDP, population, regional membership, distance, and FDI(Trade) flows. ${ }^{4}$

It is generally believed that, as countries become more developed, they tend to specialize more in production and trade more. Developed countries also have higher income levels and thus higher consumption levels than developing countries. Therefore, income variables in the home and host countries are expected to have a positive effect on bilateral trade flows between the two economies. On the supply side, an increase in income will indicate greater production available for exports. On the demand side, a rise in income, given a relatively high marginal propensity to import, will lead to an increase in imports, holding everything else constant. Therefore, we would expect GDP to have a positive effect on bilateral trade and, hence, positive coefficients for both home and host countries.

2. A full model of the simultaneous determination of bilateral trade and investment will be needed in order to deal with the possibility of simultaneity bias, which is beyond our objective of this study. When conducting estimation, we can either use the lagged variable of trade/FDI as an explanatory variable or introduce proper instrumental variables, both of which are, however, not complete solutions. For discussion of this issue in the gravity model estimation, see Frankel et al (1995) and Frankel (1997).

3. APEC - Asia Pacific Economic Cooperation, ASEAN - Association of South East Asian Nations, and DAE - Dynamic Asian Economies. We have formulated our own grouping for the DAE group, composed of the nine most dynamic members of the region: Hong Kong, Indonesia, Japan, Korea, Malaysia, Philippines, Singapore, Taiwan, and Thailand. China would have been included if a more complete data series was available.

4. More recently, the model has been written where GDP is entered into the equation in product form. However, both forms are acceptable and here, the non-product form performed slightly better than the product form of the equation. The basic results of the two forms were the same. 
The expected sign for GDP in the FDI equation is more ambiguous. It is well documented that most FDI flows take place among developed countries. Assuming that these FDI flows are not taken in search of cost-saving but rather market-penetration, one would expect a positive relationship between FDI flows and GDP in the host country as well as in the home country. Large and developed countries also tend to breed large companies which are capable of overseas FDI activities, leading to a positive coefficient of the home GDP. However, when FDI activities are motivated for the costsaving purpose, utilizing abundant skilled and non-skilled labor and natural resources in the local markets of developing countries, a negative sign on the coefficient of the host GDP in the FDI equation is expected.

While GDP proxies the economy's wealth and production capacity, population proxies market size and potential for purchasing power. ${ }^{5}$ A larger population may indicate a large domestic market and lead to a decreased need for trade and overseas investment. To the contrary, an economy with a smaller population, indicating a limited domestic market, would seek for the overseas market opportunities to exploit economies of scale. Thus, the home country population is expected to have a negative sign for both trade and FDI flows. A large host country population, however, would entice trade and foreign investment to meet domestic demand for products and capital. Firms also tend to have a physical presence in markets that they deem to be essential. Thus, the host population is expected to have a positive sign for trade and FDI flows. Overpopulation, as in many populous developing countries in the Asia-Pacific region, however, may deter an effective hosting of foreign products and investment, especially at their early stages of econom-

5. The model was also run using per capita income (PCI) as a proxy for market size or potential. However, the model using population performed better. A possible explanation is that the GDP variable already captured the country's wealth, and thus market size or potential for purchasing power is more purely captured through population variable. Of course, China and India immediately come to mind when considering countries with large population and limited current market performance. However, the large FDI flows into China in recent years indicates that population may be in some instances a better explanatory variable when income is already captured through GDP. 
ic development and emerging markets. This implies a possibility of a negative sign of the host population in the trade equation as well as the FDI equation. Therefore, the sign for the host country population variable is an empirical question.

The distance variable captures additional costs and longer time imposed by shipping products in the greater distances, among others, and thus is expected to have a negative sign for trade. Further distances may encourage firms to invest directly in the remote host market, implying a positive sign of the distance variable in the FDI equation. However, greater distances usually mean unfamiliar language, culture, and higher transaction costs, and, accordingly, may detract from the FDI activities. Thus, the expected sign of the distance variable in the FDI gravity equation is not clear.

When both country $i$ and country $j$ are members of a regional grouping, this regional effect is captured by the membership dummy. If the regional dummies are significant, it would indicate that such groupings affect trade and FDI flows over and above distance factors. That is, the regional grouping enhances, if positive, trade and FDI flows beyond what can be explained simply by the fact that they are located close to each other. A positive sign on a membership dummy would indicate that common membership in a regional economic organization increases trade and FDI flows between the two countries.

What is unknown is the sign of the FDI variable in the trade equation and that of the trade variable in the FDI equation. Resource extraction and outsourcing FDI tend to lead to an increased trade on a complementary basis, and would indicate a positive sign. However, FDI motivated by barriers to trade or market penetration would tend to be a substitute for trade and indicate a negative sign. The signs of the FDI/trade variables in the trade/FDI gravity equations, therefore, will be determined empirically.

\section{B. The Data}

The gravity model of bilateral trade, in its most basic form, says that the total trade flows (exports plus imports, i.e., $\operatorname{trade}_{i j}=\operatorname{trade}_{j i}$ ) between country $i$ and country $j$ is proportional to the product of $G D P_{i}$ and $G D P_{j}$ and inversely related to the distance between them. (Frankel 1997) Instead of 
using total bilateral flows between pairs of countries, we used a stricter form of the gravity equation by dealing a bilateral trade flow from country $i$ to country $j$ (trade $e_{i j}$ ) differently from a bilateral trade flow from country $j$ to country $i$ (trade $e_{j i}$ ). By the same token, we made a distinction between $F D I_{i j}$ and $F D I_{j i}$. Accordingly, we introduced the notion of the exporting country (home country for FDI) and the importing country (host country for FDI) in the regression, and were able to examine the role of each country in determining trade (FDI) flows. We decided, therefore, to have separate terms for income $\left(G D P_{i}\right.$ and $\left.G D P_{j}\right)$ and population $\left(P o p_{i}\right.$ and $\left.P o p_{j}\right)$ in the regression, rather than using the product of income (population also) of pairs of countries that the traditional gravity model often adopt. To this end, we needed import and export data for trade and inflow and outflow data for FDI for each pair of countries that we examined in this study.

We collected data for bilateral trade, exports and imports, and FDI flows, inflows and outflows, for the selected group of countries, during the years 1987 through 1993. Given our focus on the Asia-Pacific region, we centered our country selection around the nine major economies of East Asia, as already defined by the DAE dummy variable, as well as China, India, and Australia, and other major trading partners. We attempted to keep the data sets consistent across time periods for better comparisons. Bilateral trade data were obtained from the IMF's Direction of Trade Statistics Yearbook for various years. Other data were collected from the IMF's International Financial Statistics for various years.

The data for bilateral FDI flows were obtained from the UN's World Investment Directory for various years, OECD's Foreign Direct Investment Statistics Yearbook, and individual country source data. The individual country sources for the data include Bank of Japan's Quarterly Bulletin, Bank of Korea's Quarterly Review, Bank of Indonesia's Quarterly Review, Bank Negara Malaysia's Quarterly Bulletin, Bank of Thailand' Quarterly Bulletin, Singapore Economic Development Board's Annual Yearbook, and Taiwan's Statistical Data Book.

We graphed the total trade and FDI flows of the dynamic Asian economies (DAEs) to see if any pattern could be discerned from the aggregate flows themselves. Figure 1 shows the trend of total trade (imports plus exports) and total FDI (inflows plus outflows) in the DAEs. It would appear that the 
flows complement one another, or run together. Both flows show steady increases across the time period (1970 through 1994). This, in itself, however, means little as it is difficult to determine exactly how much of the trade is related to FDI. FDI flows tend to be more volatile after 1985, experiencing a sharp increase every year until 1990, when the worldwide recession set in and FDI flows fell around the world.

Figure 2 shows the relationship between FDI inflows and the imports and exports of the DAEs. The FDI inflows seems to fluctuate around the exports line relatively more than the imports line. This may indicate that FDI inflows lead to enhanced trade through exports, thus implying a complementary relationship. ${ }^{6}$ Whether FDI flows are trade-enhancing activities or trade-induced activities would have important implications for trade, foreign investment, and growth policies in the export-driven growth region of the Asia-Pacific developing countries. In Figure 3, FDI outflows do not appear to show the similar degree of a close relationship with trade flows as FDI inflows had.

On a preliminary basis, one can draw the conclusion from the graphs that FDI and trade are complements and that exports and FDI inflows appear to have a stronger relationship than the other flows among the DAEs. This is consistent with the export-led growth strategies and the recent open-door policies for foreign investment, with the varying speed of opening and degree of limitations on the complete openness, followed by many countries in the region. A more rigorous empirical study on the relationship between bilateral trade and FDI flows in the Asia-Pacific economies follows in the next section.

6. In a related paper, "The Cointegration Relationship between Foreign Direct Investment and Trade in the Asia Pacific Region," we showed that there was indeed a long run relationship between exports and FDI inflows among the DAEs. 


\section{Total Trade}

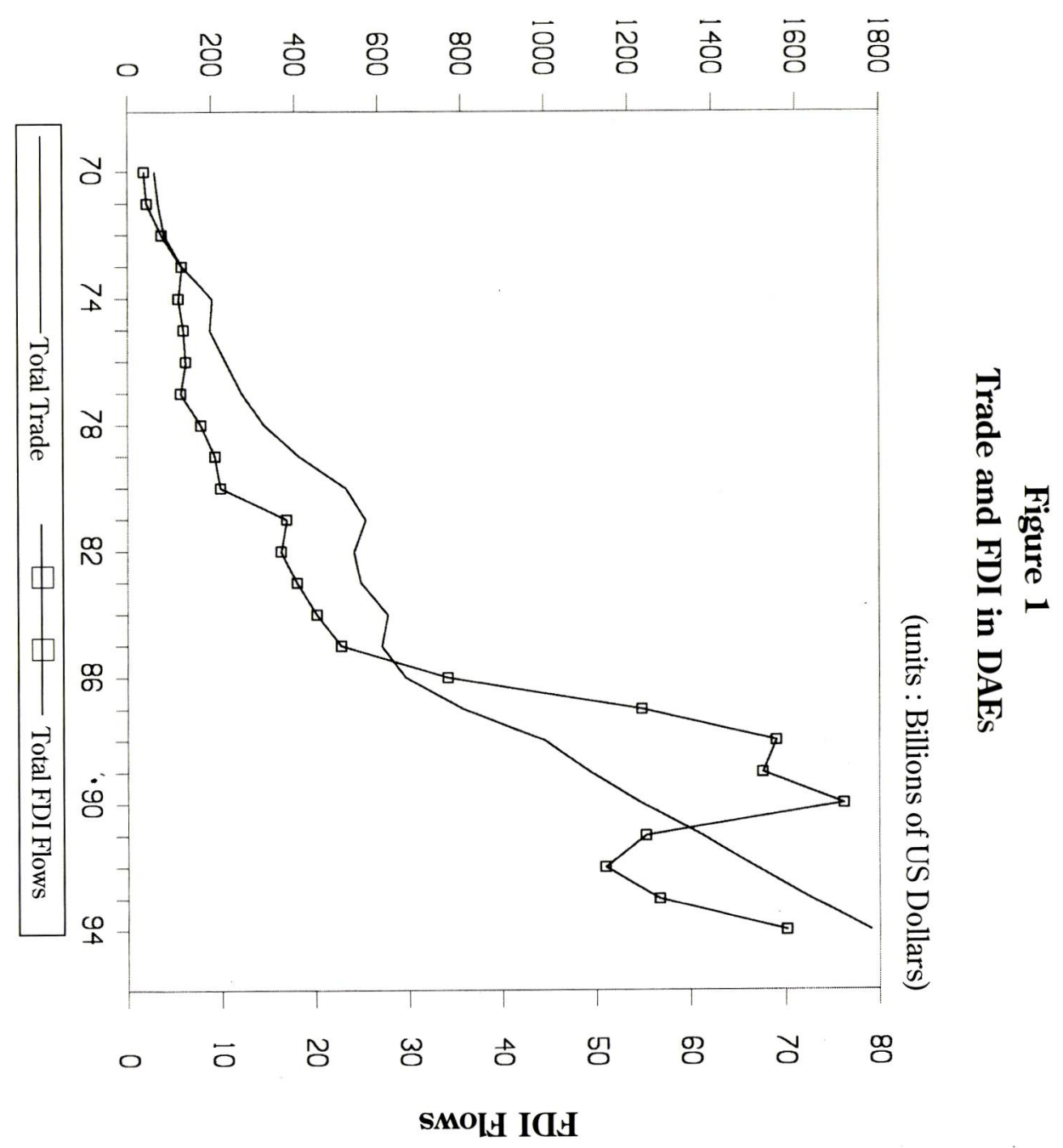


Exports and Imports

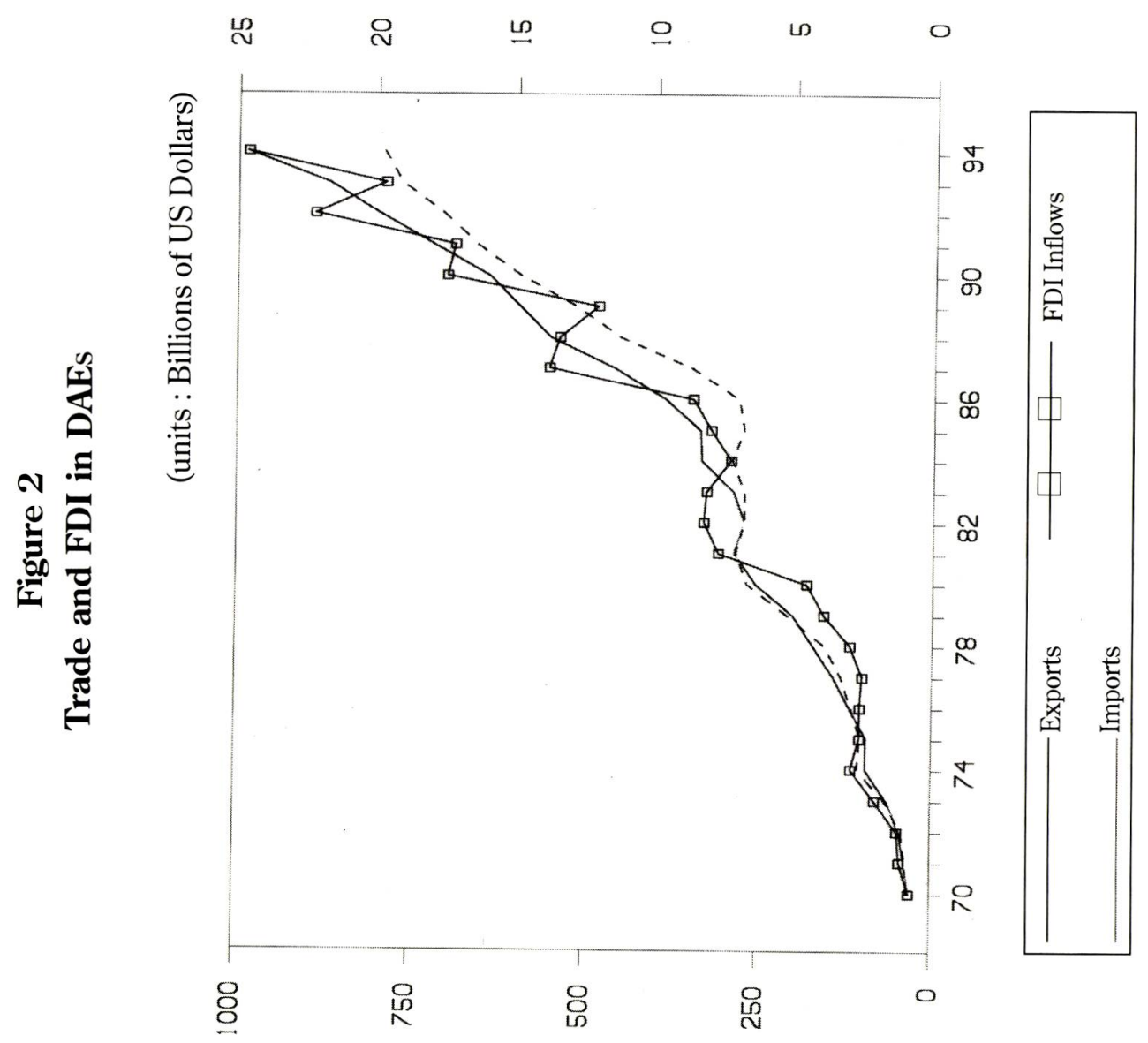

SMIOJUI IGH 


\section{FDI Outflows}

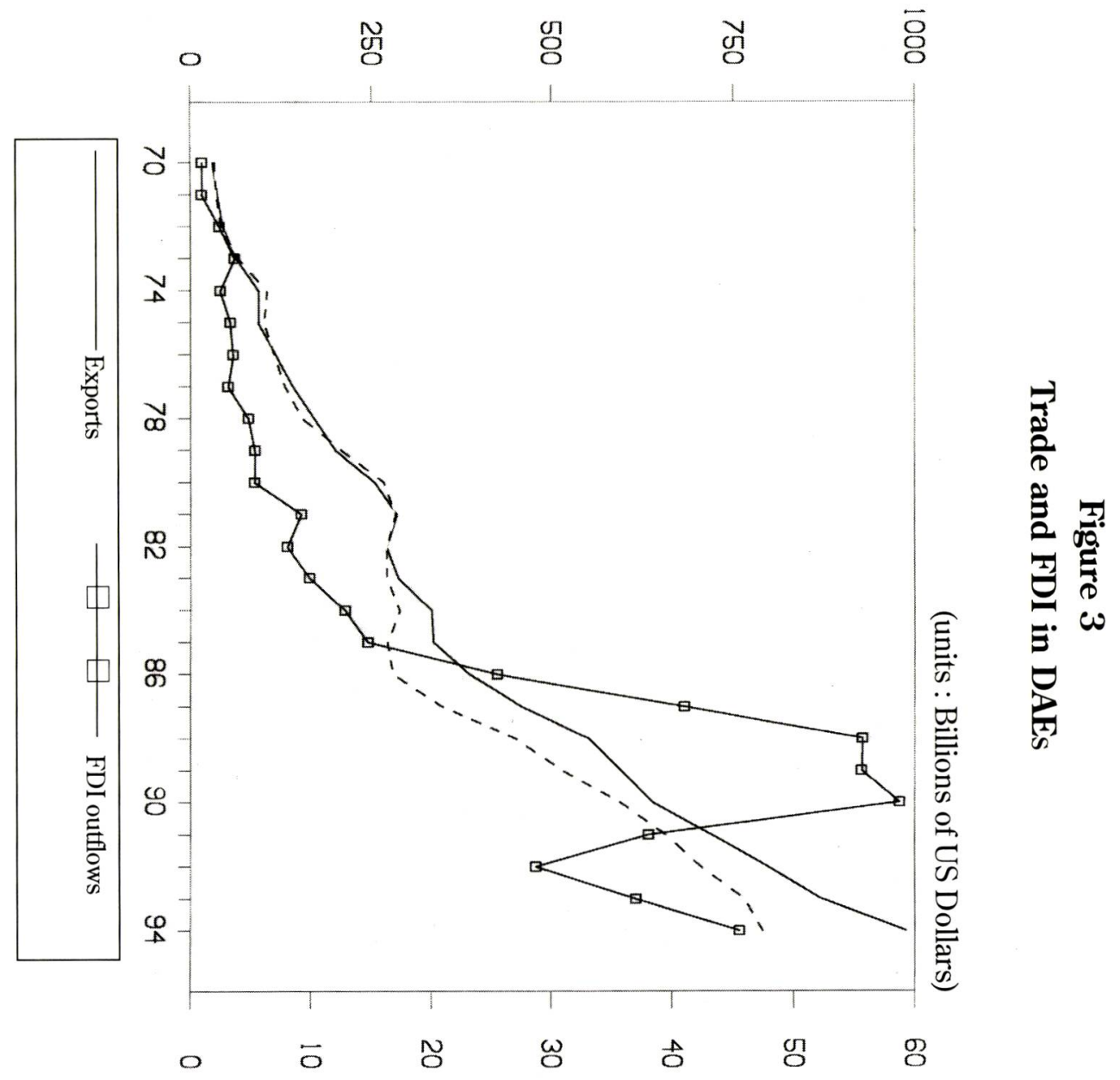

sł.IoduI pue sł.odx 


\section{Empirical Evidence}

We report the results of the cross-sectional estimations of the gravity equation for trade and FDI flows in each of the seven years between 1987 and 1993 in Tables 1 and 2. Table 1 reports the results when trade is the dependent variable, and table 2 reports when FDI flows is the dependent variable. Table 1 shows, most importantly, that the coefficient of the FDI variable is positive-signed and highly significant each year. It indicates that, first, trade and FDI flows have a complementary relationship, and, second, FDI enhances bilateral trade flows. The trade-enhancing effect of FDI, however, does not seem to be particularly strong. Regression results imply that, for every one percent increase in bilateral FDI flows, trade between the two countries increases at most by a little more than 0.2 percent. The overall performance of fit of the gravity model to the data for the trade equation seems impressively good with around 80 percent of R-squared $\left(\mathrm{R}^{2}\right)$.

Table 1 also shows that the coefficients of both the home (exporting country's) GDP and the host (importing country's) GDP are positive and statistically significant every year. This would give evidence to the positive relationship between market wealth (or production capacity) and bilateral trade flows, suggesting that higher income countries tend to specialize and trade more with each other than with lower income countries. The size of the coefficients of the home GDP variable has been in the range of 0.3 to 0.5 , while that of the host GDP variable has been, for the most part, around 0.6. Although coefficients for both home GDP and host GDP have shown slightly declining trends in recent years, the coefficient of the host GDP has been consistently larger than that of the home GDP. For example, in 1993, every one percent increase in the host GDP and the home GDP was responsible for increasing trade between the two countries by 0.468 percent and 0.308 percent, respectively.

The coefficients of market size, or potential, proxied by population, showed mixed results. Although the home country population seems to be an insignificant factor in explaining bilateral trade flows, the host country population is evidenced to be an important factor, showing negative and sta tistically significant signs for its coefficients every year. The significance of the coefficient, with a negative sign, for the host country population and the 
Table 1

Estimates of Gravity Equation with Trade as Dependent Variable

\begin{tabular}{|c|c|c|c|c|c|c|c|}
\hline & 1987 & 1988 & 1989 & 1990 & 1991 & 1992 & 1993 \\
\hline \multirow{2}{*}{ Constant } & 0.128 & 0.364 & 0.236 & -1.202 & 0.511 & -0.792 & 1.297 \\
\hline & (0.938) & $(0.866)$ & $(0.947)$ & $(-1.237)$ & (1.058) & $(-1.383)$ & (1.019) \\
\hline \multirow{2}{*}{ Home GDP } & $0.411^{\star \star \star}$ & $0.427^{\star \star \star}$ & $0.390^{\star \star \star}$ & $0.478^{\star \star \star}$ & $0.461^{\star \star \star}$ & $0.459^{\star \star \star}$ & $0.308^{\star * *}$ \\
\hline & $(0.058)$ & $(0.054)$ & $(0.057)$ & $(0.076)$ & $(0.075)$ & $(0.091)$ & $(0.067)$ \\
\hline \multirow{2}{*}{ Host GDP } & $0.607^{\star \star \star \star}$ & $0.615^{\star \star \star}$ & $0.600^{\star * *}$ & $0.607^{\star * *}$ & $0.599^{* * *}$ & $0.589^{\star \star *}$ & $0.468^{* * *}$ \\
\hline & $(0.039)$ & $(0.039)$ & $(0.043)$ & $(0.053)$ & $(0.043)$ & $(0.056)$ & $(0.04)$ \\
\hline \multirow{2}{*}{ Home Population } & -0.047 & -0.067 & 0.079 & 0.056 & 0.001 & -0.031 & 0.065 \\
\hline & $(0.057)$ & $(0.0545)$ & $(0.053)$ & $(0.081)$ & $(0.085)$ & $(0.107)$ & $(0.074)$ \\
\hline \multirow{2}{*}{ Host Population } & $-0.18^{\star \star \star}$ & $-0.17^{\star \star \star}$ & $-0.19^{\star \star \star}$ & $-0.12^{\star \star}$ & $-0.21^{\star \star \star}$ & $-0.26^{\star \star *}$ & $-0.11^{\star * *}$ \\
\hline & $(0.042)$ & $(0.039)$ & $(0.043)$ & $(0.057)$ & $(0.050)$ & $(0.049)$ & $(0.040)$ \\
\hline \multirow[b]{2}{*}{ Distance } & $-0.55^{\star \star \star}$ & $-0.58^{\star \star *}$ & $-0.55^{\star \star \star}$ & $-0.53^{\star * \star}$ & $-0.64^{* * *}$ & $-0.47^{\star * *}$ & $-0.43^{\star * *}$ \\
\hline & $(0.049)$ & $(0.049)$ & $(0.048)$ & $(0.06)$ & $(0.056)$ & $(0.075)$ & $(0.054)$ \\
\hline \multirow{2}{*}{$F D I$} & $0.165^{\star \star \star}$ & $0.151^{\star \star \star}$ & $0.141^{\star \star \star}$ & $0.095^{\star \star \star}$ & $0.131^{\star \star \star}$ & $0.210^{\star \star \star}$ & $0.213^{\star \star *}$ \\
\hline & $(0.023)$ & $(0.023)$ & $(0.025)$ & $(0.031)$ & $(0.029)$ & $(0.031)$ & $(0.028)$ \\
\hline \multirow{2}{*}{ APEC bloc } & $0.229^{\star}$ & 0.072 & $0.288^{\star *}$ & $0.266^{\star \star}$ & $0.465^{\star \star \star}$ & $0.498^{\star * *}$ & $0.512^{\star * *}$ \\
\hline & $(0.132)$ & $(0.123)$ & $(0.124)$ & $(0.131)$ & $(0.128)$ & $(0.156)$ & $(0.131)$ \\
\hline \multirow{2}{*}{ ASEAN bloc } & $-0.416^{\star}$ & $-0.510^{\star *}$ & -0.380 & $-0.748^{\star \star}$ & -0.219 & -0.012 & -0.045 \\
\hline & $(0.256)$ & $(0.231)$ & $(0.266)$ & $(0.339)$ & $(0.243)$ & $(0.245)$ & $(0.311)$ \\
\hline \multirow{2}{*}{$D A E$ group } & $0.491^{\star \star \star}$ & $0.407^{\star \star \star}$ & $0.355^{\star \star}$ & $0.429^{\star \star \star}$ & 0.047 & -0.041 & 0.080 \\
\hline & $(0.158)$ & $(0.143)$ & $(0.160)$ & $(0.179)$ & $(0.714)$ & $(0.204)$ & $(0.206)$ \\
\hline Adjusted $\mathrm{R}^{2}$ & $81.9 \%$ & $80.6 \%$ & $81.5 \%$ & $77.4 \%$ & $82.1 \%$ & $86.8 \%$ & $76.9 \%$ \\
\hline SSE & 0.684 & 0.667 & 0.645 & 0.655 & 0.626 & 0.562 & 0.683 \\
\hline D.W. & 1.56 & 1.61 & 1.61 & 1.63 & 1.67 & 1.57 & 1.58 \\
\hline White Test & 0.388 & 0.398 & 0.418 & 0.648 & 1.490 & 0.839 & 0.225 \\
\hline $\begin{array}{l}\text { Number of } \\
\text { observations }\end{array}$ & 225 & 230 & 215 & 150 & 155 & 100 & 195 \\
\hline
\end{tabular}

Note: Coefficients are reported with their standard errors in parentheses. ${ }^{*},{ }^{* *}$ and ${ }^{* \star *}$ represent significance at the $10 \%, 5 \%$ and $1 \%$ levels, respectively. The White test was conducted to detect heteroskedacity in the error term. D.W. refers to the Durbin-Watson test for auto-correlation in the error term. 
lack of the significance of that for the home country population would seem to indicate that; first, the host country size is more important than the home market size; second, a smaller economy is expected to have a more open economy; and third, a large, sometimes overcrowded, population with a low per capita income has a somewhat deterring effect, with a coefficient size of around 0.2 , on the bilateral trade flows in the region. It would take time in the process that, in densely populated developing countries, at their early stages of economic development, in the Asia-Pacific region, market potential, proxied by population, is transformed to a realized purchasing power with high per capita income. Another conjecture would be that a developing economy with low per capita income and large population might pursue protectionist trade policies. When the positive coefficient of host GDP and the negative sign of host population convince us that a small country with higher per capita income tends to have an open economy and import more, predicting that a one percent rise in per capita GDP increases imports by about 0.6 to 0.7 percent.

The coefficient of the distance variable has the expected negative sign and is statistically very significant. The coefficients of the log of the distance range from 0.43 to 0.64 , indicating that a one percent increase in the distance between two economies lowers their trade flows anywhere from 0.43 percent to 0.64 percent. The geographical distance between two economies, which may represent transportation costs and cultural differences, is evidenced to play a very important role in determining bilateral trade flows in the region.

The dummy variables representing trading bloc effects exhibit varying degrees of significance. The coefficient of the APEC dummy has been positive and highly statistically significant every year after 1989 from 0.288 to 0.512 in 1993 when the APEC was formally established, and the size of the coefficient has increased ever since with the stronger statistical significance level. This provides evidence on the significant contributing effect of the APEC to enhancing the economic independence and trade in the Asia-Pacific region in recent years since its inception in 1989. The ASEAN dummy is, however, always negative and significant in some years, indicating that the ASEAN country membership was not very successful in enhancing intragroup trade among the ASEAN nations. ${ }^{7}$ It is consistent with the reality that 
the growth rates of ASEAN nations' trade with the non-ASEAN member nations, including the U.S., Japan, and European countries, have been higher than those of ASEAN intra-group trade. It confirms a competing, rather than complementary, nature of the intra-group trade pattern observed among ASEAN nations, which have caused serious concerns to trade-policy makers in the region since its inception in 1967.

The ASEAN Free Trade Area (AFTA), launched in 1992, evidently had a limited impact on the intra-group trade among ASEAN member nations. The DAE dummy variable showed positive and statistically significant coefficients in earlier years. However, it ceased to be significant after 1991. Gaining significance for the APEC dummy and losing significance for the DAE and ASEAN dummies around the year of 1990 could be interpreted as evidence of shifting regional integration core toward APEC, and of a greater role of APEC in promoting trade in the Asia-Pacific region.

The estimation results for the gravity equation with FDI flows as the dependent variable are reported in Table 2. Most importantly, the coefficient of the trade variable is highly significant across the entire period and has a positive sign, as expected. The size of the coefficient has fluctuated but remained above the size of the FDI coefficient in the trade equation. In 1993 , for example, a one percent increase in bilateral trade led to a 1.11 percent increase in FDI flows between the two countries. Throughout the sample period, a one percent increase in trade was associated with an increase in FDI flows by somewhere between 0.65 percent and 1.64 percent, which are significantly greater than the $0.1-0.2$ percent range of the coefficients of the FDI variable in the trade equation, as reported in Table 1.

These results provide evidence that trade has a larger impact on FDI flows than FDI flows have on trade. It is also suggested that bilateral FDI flows were greatly enhanced by bilateral trade flows, and trade-driven FDI flows were more prevalent than other types of FDI, at least, over the sample period in the Asia-Pacific economies. Most importantly, the positive correlations

7. Similar results of negative signs for regional dummies have been found for certain regional economic integration groups, especially those composed of LDCs, including ASEAN and LAFTA (Latin American Free Trade Association). See, for example, Braga el al. (1996). 
Table 2

Estimates of Gravity Equation with FDI as Dependent Variable

\begin{tabular}{|c|c|c|c|c|c|c|c|}
\hline & 1987 & 1988 & 1989 & 1990 & 1991 & 1992 & 1993 \\
\hline Constant & $\begin{array}{c}-12.70^{\star \star \star} \\
(2.301)\end{array}$ & $\begin{array}{c}-11.40^{\star \star \star} \\
(2.166)\end{array}$ & $\begin{array}{c}-11.70^{\star \star *} \\
(2.292)\end{array}$ & $\begin{array}{c}-13.30^{\star * *} \\
(3.056)\end{array}$ & $\begin{array}{c}-8.40^{\star \star \star} \\
(2.710)\end{array}$ & $\begin{array}{l}-7.10^{\star} \\
(3.795)\end{array}$ & $\begin{array}{c}-7.10^{\star \star \star} \\
(2.277)\end{array}$ \\
\hline Home GDP & $\begin{array}{c}0.650^{\star \star \star} \\
(0.164)\end{array}$ & $\begin{array}{c}0.696^{\star \star \star} \\
(0.157)\end{array}$ & $\begin{array}{c}0.756^{\star \star \star} \\
(0.154)\end{array}$ & $\begin{array}{l}1.113^{* * *} \\
(0.206)\end{array}$ & $\begin{array}{c}0.795^{\star \star *} \\
(0.212)\end{array}$ & $\begin{array}{l}0.210 \\
(0.288)\end{array}$ & $\begin{array}{c}0.529^{* * *} \\
(0.156)\end{array}$ \\
\hline Host GDP & $\begin{array}{l}-0.089 \\
(0.149)\end{array}$ & $\begin{array}{l}-0.107 \\
(0.152)\end{array}$ & $\begin{array}{l}0.150 \\
(0.155)\end{array}$ & $\begin{array}{l}0.112 \\
(0.194)\end{array}$ & $\begin{array}{l}-0.247 \\
(0.173)\end{array}$ & $\begin{array}{c}0.650^{\star \star \star} \\
(0.226)\end{array}$ & $\begin{array}{l}-0.183 \\
(0.120)\end{array}$ \\
\hline Home Population & $\mid \begin{array}{c}-0.380^{* * *} \\
(1.148)\end{array}$ & $\begin{array}{c}-0.490^{\star * *} \\
(0.141)\end{array}$ & $\begin{array}{c}-0.690^{* * *} \\
(0.128)\end{array}$ & $\begin{array}{c}-0.720^{\star \star \star} \\
(0.202)\end{array}$ & $\begin{array}{c}-0.810^{\star \star \star} \\
(0.215)\end{array}$ & $\begin{array}{l}-0.559^{\star} \\
(0.294)\end{array}$ & $\begin{array}{c}-0.490^{\star * *} \\
(0.165)\end{array}$ \\
\hline Host Population & $\begin{array}{l}-0.044 \\
(0.115)\end{array}$ & $\begin{array}{l}-0.020 \\
(0.108)\end{array}$ & $\begin{array}{l}-0.087 \\
(0.117)\end{array}$ & $\begin{array}{l}-0.208 \\
(0.153)\end{array}$ & $\begin{array}{l}0.086 \\
(0.141)\end{array}$ & $\begin{array}{c}0.393^{\star \star \star} \\
(0.051)\end{array}$ & $\begin{array}{l}-0.045 \\
(0.093)\end{array}$ \\
\hline Distance & $\begin{array}{c}0.157 \\
(0.161)\end{array}$ & $\begin{array}{c}0.093 \\
(0.165)\end{array}$ & $\begin{array}{l}-0.065 \\
(0.159)\end{array}$ & $\begin{array}{l}-0.056 \\
(0.196)\end{array}$ & $\begin{array}{c}0.033 \\
(0.205)\end{array}$ & $\begin{array}{l}0.428^{*} \\
(0.251)\end{array}$ & $\begin{array}{l}-0.048 \\
(0.143)\end{array}$ \\
\hline Trade & $\mid \begin{array}{c}1.132^{\star \star \star} \\
(0.160)\end{array}$ & $\begin{array}{c}1.063^{\star \star \star} \\
(0.164)\end{array}$ & $\begin{array}{c}0.931^{\star * *} \\
(0.168)\end{array}$ & $\begin{array}{c}0.652^{\star \star *} \\
(0.214)\end{array}$ & $\begin{array}{c}0.917^{\star \star *} \\
(0.207)\end{array}$ & $\begin{array}{c}1.642^{\star \star *} \\
(0.245)\end{array}$ & $\begin{array}{c}1.113^{\star \star \star} \\
(0.146)\end{array}$ \\
\hline APEC bloc & $\begin{array}{l}-0.396 \\
(0.349)\end{array}$ & $\begin{array}{c}0.141 \\
(0.326)\end{array}$ & $\begin{array}{l}-0.020 \\
(0.324)\end{array}$ & $\begin{array}{l}-0.220 \\
(0.348)\end{array}$ & $\begin{array}{l}-0.161 \\
(0.355)\end{array}$ & $\begin{array}{c}-1.032^{\star \star} \\
(0.448)\end{array}$ & $\begin{array}{l}-0.403 \\
(0.311)\end{array}$ \\
\hline ASEAN bloc & $\begin{array}{l}0.519 \\
(0.674)\end{array}$ & $\begin{array}{c}0.856 \\
(0.616)\end{array}$ & $\begin{array}{l}-0.752 \\
(0.687)\end{array}$ & $\begin{array}{l}1.520^{*} \\
(0.896)\end{array}$ & $\begin{array}{c}0.366 \\
(0.644)\end{array}$ & $\begin{array}{c}0.225 \\
(0.685)\end{array}$ & $\begin{array}{l}-0.556 \\
(0.709)\end{array}$ \\
\hline$D A E$ group & $\begin{array}{l}-0.068 \\
(0.422)\end{array}$ & $\begin{array}{l}-0.357 \\
(0.387)\end{array}$ & $\begin{array}{c}0.616 \\
(0.414)\end{array}$ & $\begin{array}{l}-0.056 \\
(0.481)\end{array}$ & $\begin{array}{l}-0.212 \\
(0.459)\end{array}$ & $\begin{array}{r}0.719 \\
(0.565)\end{array}$ & $\begin{array}{l}-0.427 \\
(0.468)\end{array}$ \\
\hline Adjusted $\mathrm{R}^{2}$ & $58.3 \%$ & $54.7 \%$ & $56.6 \%$ & $50.7 \%$ & $49.6 \%$ & $58.7 \%$ & $54.7 \%$ \\
\hline SSE & 1.793 & 1.769 & 1.658 & 1.717 & 1.655 & 1.571 & 1.559 \\
\hline DW & 1.61 & 2.00 & 1.75 & 2.02 & 1.88 & 1.83 & 1.87 \\
\hline White Test & 0.553 & 0.478 & 0.382 & 0.245 & 0.299 & 0.427 & 0.512 \\
\hline $\begin{array}{l}\text { Number of } \\
\text { observations }\end{array}$ & 225 & 230 & 215 & 150 & 155 & 100 & 195 \\
\hline
\end{tabular}

Note: Coefficients are reported with their standard errors in parentheses. * ${ }^{* *}$ and ${ }^{* *}$ represent significance at the $10 \%, 5 \%$ and $1 \%$ levels, respectively. The White test was conducted to detect heteroskedacity in the error term. DW refers to the Durbin-Watson test for auto-correlation in the error term. 
between trade and FDI suggest that FDI has complemented, rather than substituted for, trade in the Asia-Pacific region during the study period.

The coefficients of the home GDP and population variables are also highly significant almost every year. The positive sign of the home GDP variable and the negative sign of the home population variable together imply that high-income countries with smaller domestic markets have been more active in investing directly in overseas markets in the pursuit of the economies of scale than the countries with larger populations. The smaller the home country, the more need to expand into foreign markets to exploit economies of scale. As Table 2 indicates, however, the coefficients of the host GDP and population variables are not significant and vary in signs and magnitudes, except for the year of 1992. This implies that FDI flows in the region are driven more by the market size and income in the home country than by those in the host country, in general. It appears that FDI activities undertaken during the sample period were not overwhelmingly based on serving host markets in the region.

The coefficients on regional dummies are not statistically significant, with the exception of a couple of years, and vary in signs and magnitudes, which is a drastic contrast with the results in the trade equation, as shown in Table 1. Overall, it seems to indicate that regional arrangements have been only rarely influential in determining bilateral FDI flows during the sample period. Table 2 also shows that distance is not a significant factor in explaining FDI, with the exception of 1992. It is evident that distance between the home country and the host country is a significant resistance factor for trade, but not for FDI flows. ${ }^{8}$

\section{Conclusions}

Our empirical investigation, based on the gravity-type model of bilateral trade and FDI, provides evidence of a significant and positive relationship

8. Eaton and Tamura (1994) also found that distance inhibited FDI much less than it inhibited trade for bilateral flows between the United States and Japan. Frankel (1997), on the other hand, reported that the coefficient on distance was more significant and negative than is the case in the gravity model of trade. 
between bilateral flows of trade and FDI. It has been shown that trade and FDI are significant factors in determining the other's flow and that the relationship between the two flows is a complementary one, rather than a substituting one. In the paper, the recent regional economic integration in the Asia-Pacific region, such as APEC, is evidenced to enhance trade, while not evidenced yet in FDI flows in the region.

The trade equation showed that higher income countries tend to specialize and trade more with other higher income countries than with populous lower per capita income countries. The FDI equation, on the other hand, showed that less populous high-income countries with smaller domestic markets tend to engage in FDI activity more in the pursuit of economies of scale. The implications of the geographical distance between two economies on bilateral trade and FDI flows were found to be different. It is evident that distance between the home (exporting) country and the host (importing) country is a significant resistance factor for trade, but not for FDI flows.

Overall, judging from the R-squared $\left(\mathrm{R}^{2}\right)$ of the regression equation, the gravity equation does a better job in explaining bilateral trade than bilateral FDI flows. The gravity equations have illustrated that while trade and FDI are important in determining the other's flows, trade has a stronger impact on FDI flows than FDI does on trade. It would appear from the evidence presented here that trade has been the driving factor in the trade/FDI relationship. The regional dummy variables, representing the grouping effects of APEC, ASEAN and DAE, showed more explanatory power in the trade equation than in the FDI equation. It could then be said that these groupings are more instrumental in promoting bilateral and intra-group trade than FDI flows. Especially, the formation of APEC in 1989 seems to have enhanced economic interdependence and trade, though not FDI yet, in the Asia-Pacific region. This could be explained by the relatively primitive state of negotiations and processes on the liberalization of foreign investment and capital flows in the region.

Most recently, however, governments of the East Asian countries which have been affected by the recent financial crisis have intensified their efforts to attract FDI individually and collectively. ASEAN members have been implementing their Plan of Action on Cooperation and Promotion of Investment and, in October 1998, the members of ASEAN concluded the 
Framework Agreement to establish the ASEAN Investment Area (AIA). The agreement will create a competitive investment area with ASEAN with a more liberal and transparent investment environment so as to attract more foreign FDI flows into the region. ${ }^{9}$ These collective efforts, among others, toward liberalization and promotion of FDI during the post-crisis era have been instrumental in maintaining continuous and steady FDI flows into the region, and may be able to produce a statistically significantly positive regional effect in future empirical studies.

\section{References}

Amirahmadi, Hooshang and Weiping Wu (1994), "Foreign Direct Investment in Developing Countries," The Journal of Developing Areas 28, January; 167-190.

Anderson, James E. (1979), “A Theoretical Foundation for the Gravity Equation," The American Economic Review 69(1); 106-116.

Bank of Japan (1994), "Economic Growth in East Asia and the Role of Foreign Direct Investment," Quarterly Bulletin, February; 40-67.

Bergstrand, Jeffrey H. (1989), "The Generalized Gravity Equation, Monopolistic Competition and the Factor-Proportions Theory in International Trade," The Review of Economics and Statistics, February; 143-153.

Braga, Carlos Primo, Raed Safadi, and Alexander Yeats (1996), "Latin American Experiences with Regional Integration," in Regionalism and its Place in the Multilateral Trading System, Paris, OECD; 143-168.

Chen, Tain-Jy (1992), “Determinants of Taiwan's Direct Foreign Investment," Journal of Development Economics 39, October; 397-407. Culem, Claudy G. (1988), "The Locational Determinants of Direct Investments Among Industrialized Countries," European Economic Review 32, 1988, pp. 885-904.

9. One of the main objectives of the Framework Agreement on the ASEAN Investment AREA is to open up industries and grant national treatment to the ASEAN countries by the year 2010 and to all foreign investors by the year 2020. (UNCTAD (1999). For detailed discussions about changing FDI regulatory regimes in the case of Korea, see Jeon (2000a, b). 
Deardorff, A. (1984), "Testing Trade Theories and Predicting Trade Flows," in R.W. Jones and P.K. Kenen, eds., Handbook of International Economics 1, North-Holland, Amsterdam.

Deardorff, A. (1997), “Determinants of Bilateral Trade: Does Gravity Work in a Classical World?" in The Regionalization of the World Economy, ed., Jeffrey Frankel, Chicago, IL: University of Chicago Press.

Eaton, Jonathan, and Akiko Tamura (1994), "Bilateralism and Regionalism in Japanese and U.S. Trade and Direct Foreign Investment Patterns," Journal of the Japanese and International Economies 8; 478-510.

Frankel, Jeffrey, A., "Is Japan Establishing a Trade Bloc in East Asia and the Pacific?," in Japan's Economy After the Miracle, Mitsuaki Okabe, ed., Macmillan Press, forthcoming.

Frankel, Jeffrey, A.(1997), Regional Trading Blocs: In the World Economic System, Washington, D.C.: Institute for International Economics.

Frankel, Jeffrey, A., David Romer, and Teresa Cyrus (1995), "Trade and Growth in East Asian Countries: Cause and Effect?" presented at the AEA meetings, Washington, D.C., January.

Jeon, Bang Nam (2000a), "Financial Crisis and the Legacy of Foreign Capital in South Korea, in Political, Economic, and Diplomatic Legacies for a Post-Cold War East Asia, Frederick R. Dickinson, ed., Philadelphia, PA: Penn Center of East Asian Studies, University of Pennsylvania, forthcoming.

Jeon, Bang Nam and Se Young Ahn (2000b), "Changing Attitudes Toward Foreign Firms: An Analysis of Survey Data for Korea," Department of Economics and International Business, Drexel University.

Kojima, Kiyoshi and Terutomo Ozawa (1987), Japan's General Trading Companies: Merchant of Economic Development, Paris, OECD.

Lall, Sanjaya (1991), "Direct Investment in South-East Asia by the NIEs: Trends and Prospects," Banca Nazionale del Lavoro, No. 179; 463-480. Lucas, Robert E. (1993), "On the Determinants of Direct Foreign Investment: Evidence from East and Southeast Asia," World Development, 21(3); 391-406.

Maehara, Yasuhiro (1995), "The Role of Foreign Direct Investment in the Economies of East Asia," Economic Cooperation and Challenges in the Pacific, U.S.-Korea Academic Symposium. 
Naya, Seiji and Eric Ramstetter (1991), "Foreign Direct Investment in Asia's Developing Economies and Trade in the Asian and Pacific Region," in Direct Foreign Investment in Asias Developing Economies and Structural Change in the Asia-Pacific Region, Eric Ramstetter, ed., Westview Press, Boulder.

OECD (1995), Foreign Direct Investment: OECD Countries and Dynamic Economies of Asia and Latin America, Paris.

OECD (1993), Foreign Direct Investment Relations Between the OECD and the Dynamic Asian Economies, Paris.

Pupphavesa, Wisarn (1993), "Industrialization and the Role of Foreign Direct Investment in Thailand," in OECD's Foreign Direct Investment Relations Between the OECD and the Dynamic Asian Economies, Paris; 61-68.

Ramstetter, Eric D. (1991), Direct Foreign Investment in Asia's Developing Economies and Structural Change in the Asia-Pacific Region, Westview. Press, San Francisco.

Riedel, James (1992), “Intra-Asian Trade and Foreign Direct Investment," Asian Development Review 9(1).

Stone, Susan F. and Bang Nam Jeon (1997), "The Cointegration Relationship between Foreign Direct Investment and Trade in the Asia-Pacific Region," mimeo, Drexel University.

Thursby, Jerry G. (1987), and Marie C. Thursby, "Bilateral Trade Flows, the Linder Hypothesis and Exchange Risk," The Review of Economics and Statistics, August; 488-495.

United Nations (1993), Transnational Corporations and Management Division, Foreign Investment and Trade Linkages in Developing Countries, New York.

United Nations Conference on Trade and Development (UNCTAD) (1995, 1996, 1997, 1998 and 1999), World Investment Report.

Urata, Shujiro (1994), "Changing Patterns of Direct Investment and the Implications for Trade and Development," in Pacific Dynamics and the International Economic System, Fred Bergsten and Marcus Noland, ed., Institute for International Economics, Washington D.C.

Wei, Shang-Jin and Jeffrey Frankel (1994), "A Greater China Trade Bloc?" presented at the CES-AEA joint session, Boston. 